\title{
Foot-and-mouth-disease (FMD) virus strains and examination of exposure factors associated with FMD seropositivity of cattle herds in Nigeria during
} 2007-2009

Folorunso O. Fasina ${ }^{\mathrm{a}}$, Dana R. Connell ${ }^{\mathrm{b}}$, Oladele A. Talabi ${ }^{\mathrm{c}}$, David D. Lazarus ${ }^{\mathrm{a}}$, Gabriel A. Adeleke $^{\mathrm{d}}$, Taiwo P. Olusanya ${ }^{\mathrm{d}}$, Jorge A. Hernandez ${ }^{\mathrm{b}}$

a Department of Production Animal Studies, Faculty of Veterinary Science, University of Pretoria, Onderstepoort 0110, South Africa.

b Department of Large Animal Clinical Sciences, College of Veterinary Medicine, University of Florida, Gainesville, FL, USA

c College of Veterinary Medicine, University of Agriculture, Abeokuta, Ogun State, Nigeria. d Department of Animal Production, Olabisi Onabanjo University, Ogun State, Nigeria.

* Corresponding author at: Department of Production Animal Studies, University of Pretoria, Onderstepoort 0110 , South Africa. Telephone: +27 12529 8069; Fax: +27 12529 8396; Email: daydupe2003@yahoo.co.uk.

\begin{abstract}
New outbreaks of foot-and-mouth disease (FMD) occurred in cattle herds in Nigeria during 2007-2009. The objectives of the study reported here were (i) to identify current FMD virus strains circulating in cattle herds and (ii) to identify exposure factors associated with a seropositive diagnosis of FMD in cattle herds. This study provides evidence that FMD virus serotypes O, A and SAT-2 were co-circulating in cattle herds in Nigeria during 2007-2009. Cattle herds in a neighborhood affected with FMD had higher odds of being classified as seropositive to FMD, compared to herds that were in a neighborhood not affected with FMD $(\mathrm{OR}=16.27 ; 95 \% \mathrm{CI}=3.61,18.74 ; P<0.01)$. Cattle herds that share water points along the trek
\end{abstract}


routes with other cattle herds had higher odds of being classified as seropositive to FMD (adjusted $\mathrm{OR}=4.15 ; 95 \% \mathrm{CI}=0.92,18.74 ; P<0.06$ ). Results from this study can be used by veterinary services in Nigeria and neighboring countries to evaluate current or future FMD control and eradication programs.

Keywords: FMD; case-control; Nigeria; cattle.

\section{Introduction}

Foot and mouth disease virus (FMDV) is an RNA virus of the Picornaviridae family that naturally infects cattle and other livestock species, causing an acute illness characterized by lameness and vesicular lesions in the buccal cavity, interdigital space and teats. There are seven FMDV serotypes worldwide (O, A, C, Southern African Territories: SAT-1, SAT-2, and SAT-3, and Asia-1). The genome is over $8 \mathrm{~kb}$ in length and encode four structural proteins (SPs, VP1, VP2, VP3 and VP4) that form an icosahedral capsid, and a total of ten mature nonstructural

proteins (NSPs) (L, 2A, 2B, 2C, 3A, 3B, 3C, 3D; or some complex, such as $3 \mathrm{AB}$ or $3 \mathrm{ABC}$ ) (Mason et al., 2003; Ma et al., 2011).

Foot-and-mouth disease (FMD) is considered one of the most contagious diseases affecting economically important livestock species such as cattle, sheep, and pigs in the 2007 Terrestrial Animal Health Code by the World Organization for Animal Health (Office-International-desEpizooties) (Orsel et al., 2009). Although FMD is reported worldwide, it is particularly endemic in sub-Saharan Africa, with widespread outbreaks of clinical disease occurring almost yearly (Sahle et al., 2004; Rweyemamu et al., 2008). In sub-Saharan Africa, two cycles of FMD occur: one where the virus circulates between wildlife and domestic animals and the other where the 
virus spreads among domestic animals (Vosloo et al., 2004). In southern Africa and eastern Africa, the cycle between wildlife and domestic animals occurs, while in West Africa, due to the low numbers of wildlife, the disease is maintained mainly in domestic animals. Six serotypes (A, O, C, SAT-1, SAT-2, and SAT-3) have been identified in Africa and four in West Africa (A, O, SAT-1, and SAT-2) (Sangare et al., 2004). Disease control has become more complicated because of marked regional differences in the distribution and prevalence of various serotypes and topotypes (Knowles \& Samuel, 2003; Vosloo et al., 2004; Sahle et al., 2004).

Foot-and-mouth disease was first reported in Nigeria in 1924 in sporadic outbreaks in cattle herds attributed to serotype O virus (Libeau, 1960). Subsequently, other serotypes (A, SAT-1 and SAT-2) were identified, and each of these introductions was associated with trade of cattle entering Nigeria from neighboring countries (Owolodun, 1971; Nawathe and Goni, 1976; Durojaiye, 1981). The disease remains endemic because other transboundary animal diseases (rinderpest, African swine fever, highly pathogenic avian influenza) have been assigned higher priorities by Nigeria's national veterinary services, movement of cattle is not controlled, and vaccination is not practiced except for a few established farms that have exotic animals. Control and eradication of FMD in Nigeria is important to meet a growing population's high demand for animal protein and to access regional and international markets of animals and animal products. During 2007-2009, new outbreaks of FMD occurred in cattle herds in Nigeria. The objectives of the study reported here were (i) to identify current FMD virus strains circulating in cattle herds and (ii) to identify exposure factors associated with a seropositive diagnosis of FMD in cattle herds. 


\section{Materials and methods}

\subsection{Study site}

Nigeria is a West African country that shares largely uncontrolled land borders with the Republic of Benin in the west, Chad and Cameroon in the east, and Niger in the north. Its coasts lie on the Gulf of Guinea in the south and it borders Lake Chad to the northeast. The country has a cattle population of $\sim 16$ million (FAO, 2012) aside the countless heads of cattle that cross the various borders into the country daily. The country serves as a major meeting point for most of cattle arriving from certain West and Central African countries (Sumption et al., 2007) in view of the abundant feed resources, the enormous human population, geographic contiguity to many countries and the relative wealth/purchasing power of the country in the sub-region.

The majority of the Nigerian cattle move from the extreme north of the country down towards the south traversing the Sahel Savannah, Sudan Savannah, Guinea Savannah, the sub-humid and the humid belts of the country largely in search of available feed resources (Fadiga et al., 2011). The study cattle populations based on residency of the animals include the:

$i$. Sedentary (cattle population that are managed under a semi-intensive system, they are resident near human habitats and only rarely move within a few kilometers from human populations. Feedstuffs and water are often provided for the animals but animals are supplemented by grazing).

ii. Pastoralist (the majority of Nigerian cattle which mainly traverses the national, state and other boundaries in search of food and water. These extensively raised animals and their owners move through the different ecoclimatic zones and sometimes come into contact with wildlife and 
human habitats on their ways. The owners are often involved in conflicts with arable farmers due to damage to the crops of the latter).

iii. Cattle market (animals that may originate from any two of the above but are resident in or around the livestock markets. Such markets are well established in major cities, main boundaries and certain points along the trek routes and operators of such markets often keep a few cows which they sell from time to time).

$i v$. Others (a not well defined system of cattle residency which may be a mix of the defined populations above).

\subsection{Identification of FMD virus strains}

Between 2007 and 2009, cattle herds affected with FMD-like clinical signs (vesicular lesions in the mouth, nares, muzzle, feet and teats, excessive salivation, lameness) or oral lesions (crusting of the muzzle and erosion or ulceration of the oral mucosa) were reported to the National Veterinary Research Institute (NVRI) in Vom, Nigeria. NVRI veterinarians were assigned to conduct a disease herd investigation. During the investigation, blood serum, epithelial and vesicular fluid samples were collected from 3 to 5 affected cattle for diagnosis of FMD. In the field, an attempt was made by the attending NVRI veterinarian to collect and transport epithelium and vesicular fluid for diagnosis of FMD following Office International des Epizooties guidelines (Kitching and Donaldson., 1987).

At the NVRI, blood serum samples were processed for detection of FMDV non-structural protein (NSP) antibodies using an ELISA test (3-ABC ELISA; Prionics, Lelystad B. V., The 
Netherlands) and recommended procedures (Brocchi et al., 2006). The test detects antibodies to the FMD NSP 3-ABC antigens (expressed as a recombinant antigen using a Baculovirus) which are directly coated onto a microplate. The Optical Density (OD) of the ELISA results were measured at $450 \mathrm{~nm}$ on a Multiskan ${ }^{\circledR}$ spectrophotometer (Thermo Scientific, USA), and the results were expressed as Percentage Inhibition relative to the $\mathrm{OD}_{450}$ max. Samples with PI $\geq$ $50 \%$ were considered positive, while $\mathrm{PI}<50 \%$ negative using the formula: $\mathrm{PI}=100-\left[\mathrm{OD}_{450}\right.$ test sample/OD $\left.{ }_{450} \max \right]$ x 100 (Sorensen et al., 1998).

The 3-ABC ELISA test is used to differentiate FMD-infected from FMD-vaccinated cattle. Footand-mouth disease virus infection in cattle induces antibodies against both structural proteins (SP) and NSP. Cattle vaccinated with a NSP-free vaccine produces antibodies against SP, but not against NSP. A seropositive result is an indication of previous exposure of cattle to FMDV. The estimated specificity of the test in non-vaccinated and vaccinated cattle $=97-99 \%$ (Brocchi et al., 2006; Engel et al., 2008). The estimated sensitivity in non-vaccinated cattle $=97-100 \%$ and in vaccinated cattle $=85-86 \%$. Following NVRI's standard operating laboratory procedures, to ensure the quality control and internal validity of the ELISA test, each serum sample was tested in duplicates (two wells), and the mean value of both outcomes was used for each sample. However, for samples where the paired test outcome was not within $10 \%$ of the mean value, or where one well was positive and the other negative, a retest was conducted to confirm seropositivity or seronegativity. Similarly, a plate that has up to $20 \%$ retests ( 8 paired serum) had all the samples retested. 
In addition, as part of a cooperative agreement between the NVRI and the World Reference Laboratory for Foot and Mouth Disease (WRLFMD) in Pirbright, UK, a total of 50 epithelial and vesicular fluid samples were shipped from the NVRI to the WRLFMD for isolation and identification of FMDV strains. These samples were collected from cattle in North Central (n $=14)$, North East $(n=20)$ and South West $(n=16)$ regions of Nigeria; cattle were affected with FMD-like clinical signs and were classified as seropositive to FMDV NSP antibodies. Samples were packaged according to international standard for transportation of infectious materials affecting animals (OIE, 2008). At the WRLFMD, all samples were tested for diagnosis of FMDV by virus isolation and reverse transcription (rt) PCR (Bronsvoort et al., 2004). Virus isolation was attempted from all samples in primary bovine thyroid cell culture. All cultures showing FMDV cytopathic effect were harvested and serotyped using an ELISA. All viruses that were recovered from epithelial or vesicular fluid samples were sequenced using a WRLFMD standard protocol (Bronsvoort et al., 2004). Furthermore, a phylogenetic analysis of FMDV isolates was conducted using regions of a VP1 sequence to calculate distance values between isolates. Distances of $<5 \%$ were considered to identify same "strains", distances between 5 to $15 \%$ to indicate that the virus strain has been in the region for some time and evolved from a distant common ancestor, and distances $>15 \%$ to indicate that the virus strains are unrelated.

\subsection{Case-control study}

A case-control study was conducted to examine investigated exposure factors associated with a positive diagnosis of FMD in cattle herds. 


\subsubsection{Selection of case herds}

Case herds $(n=68)$ were those with cattle affected with FMD-like clinical signs or oral lesions and that were classified as seropositive for FMDV NSP antibodies using the 3-ABC ELISA. A herd was classified as seropositive if at least one animal in the herd was seropositive to FMDV NSP antibodies.

\subsubsection{Selection of control herds}

Control herds $(n=68)$ were randomly selected from a list of cattle herds with no evidence of FMD-like clinical signs or oral lesions that were investigated as part of an FMD outbreak investigation in 2007-2009. All cattle herds were classified as seronegative for FMDV NSP antibodies using the 3-ABC ELISA. These herds were investigated by a NVRI veterinarian because (i) the herd was within a radius of $1 \mathrm{~km}$ from a cattle herd classified as seropositive to FMDV or (ii) the herd had history of contact (physical, mouth-to mouth or same pasture/water source) with a cattle herd classified as seropositive to FMDV. Control herds were matched individually to case herds by period/date of sampling (month), herd size ( $<50,51-100,101-150$, $>150$ ) and type of operation (dairy, beef, dairy and beef).

\subsubsection{Data collection}

A structured questionnaire was developed for collection of herd-level exposure factors' data. The questionnaire was developed in collaboration with NVRI veterinarians, and it was prepared in three dialects (ie, Fulfulde, Hausa and Yoruba), and translated by native speakers for easy communication with producers in the different ethnic groups. For each cattle herd, the following 
information was collected: herd size (1-50, 51-100, 101-150, $\geq 151)$; type of operation (dairy, beef, dairy and beef); years of operation (1-5, 6-10, > 10); farmer has $>1$ practice/facility (no, yes); cattle herd residency (sedentary, pastoralist, cattle market, other); animal origin (North, South, North and South); farmer and cattle share water points on the trek with other herds (no, yes); neighboring village shares water points (no, yes); neighboring village shares grazing reserves (no, yes); farmer and cattle herd share trek route (no, yes); distance travelled per day ( $\leq$ $7 \mathrm{~km},>7 \mathrm{~km}$ ); farmer and cattle herd share pasture with other herds (no, yes); farmer and cattle cross national boundaries (no, yes); farmer and cattle cross state boundaries (no, yes); farmer and cattle cross game reserves and parks (no, yes); farmer has sighted wild ungulates/ruminants (no, yes); cattle in contact with wild animals (no, yes); there is a pig farm in the neighborhood (no, yes); cattle is used for farm work (no, yes); cattle graze with sheep (no, yes); cattle graze with goats (no, yes); cattle herd was reported by the producer as being vaccinated against FMDV (no, yes); cattle cross national highways (no, yes); use of manure from outside farms (no, yes); vehicles have free access to the farm (no, yes); there was one or more other cattle herds affected with an outbreak of FMD or FMD-like lesions in the neighborhood (a radius of $1 \mathrm{~km}$ ) in the last 30 days (no, yes); there is a cattle market in the neighborhood (no, yes); there is a meat market in the neighborhood (no, yes); there is a veterinary clinic in the neighborhood (no, yes). In this study, an outbreak of FMD in the neighborhood was defined as a new case of FMD in one or more cattle herds with report of FMD-like lesions by the farmers and confirmation through laboratory method (NSP FMD 3-ABC ELISA). A neighborhood was defined as a geographic area with several owned cattle herds within a $1 \mathrm{~km}$ radius. Such populations may exist with or without individual fences or biosecure barriers that prevent direct contact between cattle herds. 
Exposure data reflected the status of the study herd before it was classified as a case or control herd.

\subsubsection{Data analysis}

Conditional logistic regression was used to model the odds of being a case herd as a function of investigated exposure factors. Initial screening of potential risk factors for FMD was performed by the use of univariable conditional logistic regression (Hosmer and Lemeshow, 2000; Cytel Software Corporation, 2000). Exposure variables with $P$ values $\leq 0.20$ were considered for inclusion in a multivariable logistic regression analysis. Associations between exposure variables $(P \leq 0.20)$ were examined, and when a pair of variables was associated by use of a $X^{2}$ test, (two tailed), the exposure variable judged as most biologically plausible was used as a candidate in the multivariable analysis. A forward stepwise approach was used to identify variables associated with a positive diagnosis of FMD. To determine the best fitting model, the variable with the smallest $P$ value in the univariable analysis was entered into the model first. Thereafter, each of the remaining variables was added to the model containing the first variable to determine if confounding was present (eg, $10 \%$ change in the odds ratio); variables had to have a $P$ value $\leq$ 0.10 to be retained in the model. Following fitting of the main effects model, interaction terms between explanatory variables in the model (e.g., outbreak of FMD in the neighborhood and farmer and cattle herd share water point on the trek with other herds) were tested for significance using the likelihood ratio test. Fit of the final model to the data was assessed by a visual examination of residual plots (standardized delta-beta values vs observation number and deltabeta values vs fitted values). Case-control sets that had herds with extreme delta-beta values and 
low fitted values were excluded from the analysis to evaluate their influence on estimated odds ratios (OR). In the final model, the adjusted OR and 95\% confidence interval (CI) were reported.

\section{Results}

\subsection{Identification of FMD virus strains}

Results from sequencing and phylogenetic analyses revealed that FMDV serotypes $\mathrm{O}$, A and SAT-2 were co-circulating in cattle herds in Nigeria during 2007-2009. The geographic distribution of FMDV serotypes and topotypes identified in cattle herds in Nigeria during the study period is presented in Figure 1.

Two serotype $\mathrm{O}$ isolates were recovered from one cattle herd in the state of Bauchi in 2007 and one cattle herd in the state of Plateau in 2009. The phylogenetic distance between these two isolates $=5.79 \%$ (Appendix 1). In addition, the isolate from 2007 was considered the same strain as that from 3 isolates from Sudan in 2005 and 7 more in 2004. Furthermore, the isolate from 2009 was considered the same strain as that from 3 isolates from Sudan in 2005 (i.e., phylogenetic distance $<5 \%$ ).

Four serotype A isolates were recovered from one cattle herd in the state of Plateau (one isolate) and from one cattle herd in the state of Adamawa (three isolates) in 2009. The phylogenetic distance between the three isolates from Adamawa $=0.15 \%$, and the distance between the isolates from Adamawa and Plateau $=10.38$ to $10.53 \%$ (Appendix 2). The phylogenetic distance between these four isolates from Nigeria and other isolates from Cameroon (2000), Mali (2004/2006) and Eritrea (1997) ranged from 6.26 to $10.53 \%$. 
Nine serotype SAT-2 isolates were recovered from one cattle herd in Bauchi state in 2007 (1 isolate), from one cattle herd in Niger state in 2008 (5 isolates), and from three cattle herds in Plateau state in 2008 ( 3 isolates). The phylogenetic distance between these nine isolates ranged from 0.31 to $1.39 \%$ (Appendix 3). The distance between the nine isolates from Nigeria and one isolate from Sudan (2007) ranged from 4.78 to $5.25 \%$, and distance from one isolate from Niger Republic (2005) ranged from 7.10 to $7.25 \%$.

\subsection{Case-control study}

This present study included 68 case herds and 68 control herds in Nigeria. Seven of 68 case herds had one animal that tested positive to FMDV NSP antibodies. Sixty-one of 68 case herds had 2 or more animals that tested positive to FMDV NSP antibodies. Nine of the 68 case herds were confirmed as FMD-infected by virus isolation and sequencing and phylogenetic analysis of the VP1 gene, and 7 additional case herds were confirmed by rt-PCR only. The geographic distribution of case and control farms is presented in Figure 2. Most case and control herds were herds with $\leq 50$ cattle head (see Table 1 ). In the univariable analysis, 14 variables had values of $P \leq 0.20$ and were further analyzed for biological plausibility, magnitude of association, and statistical significance. The other 15 variables dropped because they were not significant include herd size (not tested); type of operation (not tested); farmer has $>1$ practice/facility $(P=0.43)$; animal origin $(P=0.56)$; distance travelled per day $(P=0.24)$; farmer and cattle cross state boundaries $(P=0.22)$; cattle in contact with wild animals $(P=0.21)$; there is a pig farm in the neighborhood $(P=0.85)$; cattle is used for farm work $(P=0.21)$; cattle graze with sheep $(P=$ $0.72)$; cattle graze with goats $(P=0.59)$; cattle herd was reported by the producer as being 


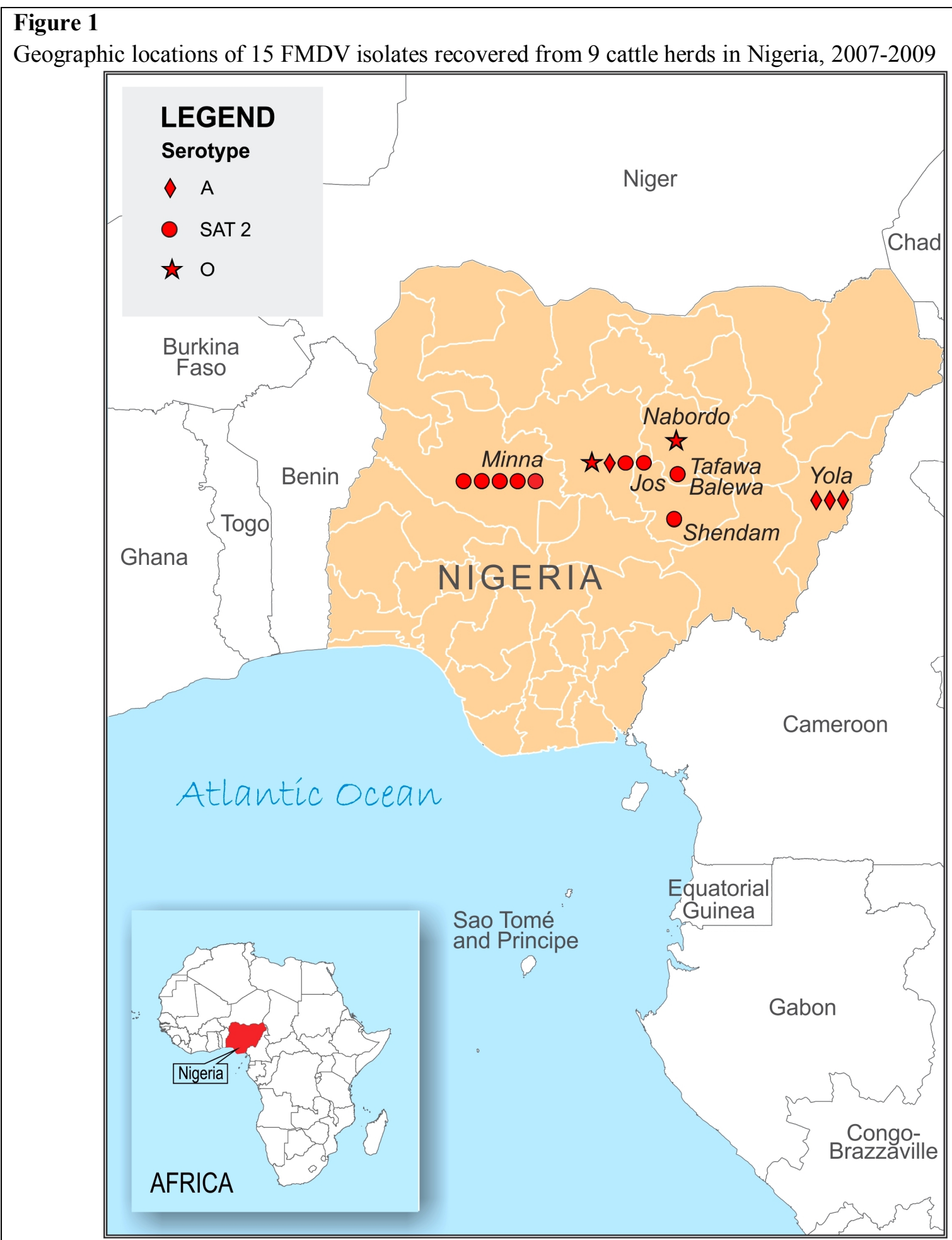

The isolates (nine SAT 2; four A and two O serotypes) were from Minna in Niger; Jos/Shendam in Plateau; Nabordo/Tafawa-Balewa in Bauchi and Yola in Adamawa states of Nigeria. 
vaccinated against FMDV $(P=0.27)$; use of manure from outside farms $(P=0.59)$; there is a meat market in the neighborhood $(P=0.37)$; there is a veterinary clinic in the neighborhood $(P=$ $0.68)$.

The explanatory variable for 'FMD outbreak in the neighborhood' was associated $(P<0.05)$ with the variable for 'cattle market in the neighborhood'. The variable for 'farmer and cattle herd share water point along the trek routes with other herds' was associated with the variables for 'neighboring village share water points' and 'neighboring village share grazing reserves'. The variable 'neighboring village share water points' was associated with the variable for 'neighboring village share grazing reserves'. Finally, the variable for 'neighboring village share grazing reserves' was associated with the variable for 'farmers and animals share trek route'.

In the multivariable analysis, the variables for 'FMD outbreak in the neighborhood' and for 'farmer and cattle herd share water point along the trek routes with other herds' were retained in the final model (Table 2). Addition to the model of the interaction term between these two variables was not significant $(P=0.48)$ and this term was removed from the model. Visual examination of residuals revealed that delta-beta values for the two variables kept in the final model were not extreme (i.e., not $>1$ ), which supported overall goodness of fit. Analysis of residuals (set of case and control herds with the largest delta-beta value and lowest fitted value) indicated the existence of influential observations; however, removal of these observations did not change the finding of greater risk associated with 'FMD outbreak in the neighborhood' and for 'farmer and cattle herd share water point along the trek routes with other herds'. 
Table 1. Univariable analysis of risk factors associated with foot-and-mouth disease virus infection on cattle farms in Nigeria; showing variables with values $p<0.20$

\begin{tabular}{|c|c|c|c|c|c|c|}
\hline Variable & Category & $\begin{array}{c}\text { Case } \\
\text { farms } \\
\mathrm{N}=68\end{array}$ & $\begin{array}{c}\text { Control } \\
\text { farms } \\
\mathrm{N}=68\end{array}$ & Crude OR & $95 \% \mathrm{CI}$ & $\mathrm{P}$ \\
\hline Years of operation & $\begin{array}{c}1-5 \\
6-10 \\
>10\end{array}$ & $\begin{array}{c}8 \\
34 \\
25\end{array}$ & $\begin{array}{l}21 \\
27 \\
20\end{array}$ & $\begin{array}{l}1.00 \\
2.88 \\
2.82\end{array}$ & $\begin{array}{l}\text { Reference } \\
1.15,7.19 \\
1.07,7.43\end{array}$ & $\begin{array}{l}\text { NA } \\
0.02 \\
0.03\end{array}$ \\
\hline Cattle herd residency & $\begin{array}{c}\text { Sedentary } \\
\text { Pastoralist } \\
\text { Cattle market } \\
\text { All others }\end{array}$ & $\begin{array}{c}16 \\
29 \\
8 \\
13\end{array}$ & $\begin{array}{c}22 \\
23 \\
2 \\
20\end{array}$ & $\begin{array}{l}1.00 \\
2.04 \\
5.42 \\
0.95\end{array}$ & $\begin{array}{c}\text { Reference } \\
0.88,4.75 \\
0.97,30.24 \\
0.34,2.61\end{array}$ & $\begin{array}{l}\text { NA } \\
0.09 \\
0.05 \\
0.92\end{array}$ \\
\hline $\begin{array}{l}\text { Farmer and cattle herd share water } \\
\text { points on the trek with other herds }\end{array}$ & $\begin{array}{l}\text { No } \\
\text { Yes }\end{array}$ & $\begin{array}{c}5 \\
62 \\
62\end{array}$ & $\begin{array}{l}15 \\
50\end{array}$ & $\begin{array}{l}1.00 \\
3.50\end{array}$ & $\begin{array}{l}\text { Reference } \\
1.15,10.63\end{array}$ & $\begin{array}{l}\text { NA } \\
0.02\end{array}$ \\
\hline $\begin{array}{l}\text { Neighboring village shares water } \\
\text { points }\end{array}$ & $\begin{array}{l}\text { No } \\
\text { Yes }\end{array}$ & $\begin{array}{l}26 \\
38\end{array}$ & $\begin{array}{l}37 \\
28\end{array}$ & $\begin{array}{l}1.00 \\
2.44\end{array}$ & $\begin{array}{l}\text { Reference } \\
1.12,5.30\end{array}$ & $\begin{array}{l}\mathrm{NA} \\
0.02\end{array}$ \\
\hline $\begin{array}{l}\text { Neighboring village shares } \\
\text { grazing reserves }\end{array}$ & $\begin{array}{l}\text { No } \\
\text { Yes }\end{array}$ & $\begin{array}{l}12 \\
50\end{array}$ & $\begin{array}{l}25 \\
37\end{array}$ & $\begin{array}{l}1.00 \\
2.57\end{array}$ & $\begin{array}{l}\text { Reference } \\
1.07,6.16\end{array}$ & $\begin{array}{l}\text { NA } \\
0.03\end{array}$ \\
\hline $\begin{array}{l}\text { Farmer and cattle herd share trek } \\
\text { route }\end{array}$ & $\begin{array}{l}\text { No } \\
\text { Yes }\end{array}$ & $\begin{array}{l}10 \\
56\end{array}$ & $\begin{array}{l}21 \\
42 \\
\end{array}$ & $\begin{array}{l}1.00 \\
2.22 \\
\end{array}$ & $\begin{array}{l}\text { Reference } \\
1.01,4.88 \\
\end{array}$ & $\begin{array}{l}\mathrm{NA} \\
0.04 \\
\end{array}$ \\
\hline $\begin{array}{l}\text { Farmer and cattle herd share } \\
\text { pasture with other herds }\end{array}$ & $\begin{array}{l}\text { No } \\
\text { Yes }\end{array}$ & $\begin{array}{l}22 \\
35\end{array}$ & $\begin{array}{l}30 \\
30\end{array}$ & $\begin{array}{l}1.00 \\
1.87\end{array}$ & $\begin{array}{l}\text { Reference } \\
0.79,4.42\end{array}$ & $\begin{array}{l}\mathrm{NA} \\
0.15\end{array}$ \\
\hline $\begin{array}{l}\text { Farmer and cattle cross national } \\
\text { boundaries }\end{array}$ & $\begin{array}{l}\text { No } \\
\text { Yes }\end{array}$ & $\begin{array}{l}52 \\
15\end{array}$ & $\begin{array}{c}56 \\
8\end{array}$ & $\begin{array}{l}1.00 \\
2.00\end{array}$ & $\begin{array}{l}\text { Reference } \\
0.80,4.95\end{array}$ & $\begin{array}{l}\text { NA } \\
0.13\end{array}$ \\
\hline $\begin{array}{l}\text { Farmer and cattle cross game } \\
\text { reserves and parks }\end{array}$ & $\begin{array}{l}\text { No } \\
\text { Yes }\end{array}$ & $\begin{array}{l}55 \\
11\end{array}$ & $\begin{array}{c}61 \\
4\end{array}$ & $\begin{array}{l}1.00 \\
2.50\end{array}$ & $\begin{array}{l}\text { Reference } \\
0.78,7.97\end{array}$ & $\begin{array}{l}\text { NA } \\
0.12\end{array}$ \\
\hline $\begin{array}{l}\text { Farmer has sighted wild } \\
\text { ungulates/ruminants }\end{array}$ & $\begin{array}{l}\text { No } \\
\text { Yes }\end{array}$ & $\begin{array}{l}49 \\
17\end{array}$ & $\begin{array}{l}54 \\
10\end{array}$ & $\begin{array}{l}1.00 \\
2.00\end{array}$ & $\begin{array}{l}\text { Reference } \\
0.80,4.95\end{array}$ & $\begin{array}{l}\text { NA } \\
0.13\end{array}$ \\
\hline $\begin{array}{l}\text { FMD outbreak in the } \\
\text { neighborhood }\end{array}$ & $\begin{array}{l}\text { No } \\
\text { Yes }\end{array}$ & $\begin{array}{l}17 \\
42\end{array}$ & $\begin{array}{l}49 \\
12\end{array}$ & $\begin{array}{c}1.00 \\
14.50\end{array}$ & $\begin{array}{l}\text { Reference } \\
3.46,60.76\end{array}$ & $\begin{array}{c}\mathrm{NA} \\
<0.01\end{array}$ \\
\hline Cattle market in the neighborhood & $\begin{array}{l}\text { No } \\
\text { Yes }\end{array}$ & $\begin{array}{l}13 \\
55\end{array}$ & $\begin{array}{l}19 \\
45\end{array}$ & $\begin{array}{l}1.00 \\
2.60\end{array}$ & $\begin{array}{l}\text { Reference } \\
0.92,7.29\end{array}$ & $\begin{array}{l}\mathrm{NA} \\
0.06\end{array}$ \\
\hline Cattle cross national highways & $\begin{array}{l}\text { No } \\
\text { Yes }\end{array}$ & $\begin{array}{l}31 \\
36\end{array}$ & $\begin{array}{l}35 \\
24\end{array}$ & $\begin{array}{l}1.00 \\
1.75\end{array}$ & $\begin{array}{l}\text { Reference } \\
0.86,3.55\end{array}$ & $\begin{array}{l}\mathrm{NA} \\
0.12 \\
\end{array}$ \\
\hline $\begin{array}{l}\text { Vehicles have free access to the } \\
\text { farm }\end{array}$ & $\begin{array}{l}\text { No } \\
\text { Yes }\end{array}$ & $\begin{array}{l}15 \\
52\end{array}$ & $\begin{array}{l}18 \\
42\end{array}$ & $\begin{array}{l}1.00 \\
1.77\end{array}$ & $\begin{array}{l}\text { Reference } \\
0.78,4.02\end{array}$ & $\begin{array}{l}\text { NA } \\
0.16\end{array}$ \\
\hline
\end{tabular}


Table 2. Multivariable analysis of risk factors associated with foot-and-mouth disease virus infection on cattle farms in Nigeria

\begin{tabular}{|l|c|c|c|c|c|}
\hline Variable & Coefficient & $\begin{array}{c}\text { Standard } \\
\text { error }\end{array}$ & Adjusted OR & $95 \%$ CI & $P$ \\
\hline $\begin{array}{l}\text { Model 1 } \\
\text { FMD outbreak in the neighborhood }\end{array}$ & 2.7895 & 0.7680 & 16.27 & $3.61,73.31$ & $<0.01$ \\
$\begin{array}{l}\text { Farmer and cattle herd share water points } \\
\text { on the trek with other herds }\end{array}$ & 1.4243 & 0.7687 & 4.15 & $0.92,18.74$ & 0.06 \\
\hline $\begin{array}{l}\text { Model 2* } \\
\text { FMD outbreak in the neighborhood }\end{array}$ & 3.4181 & 1.0487 & 30.51 & $3.90,283.30$ & $<0.01$ \\
$\begin{array}{l}\text { Farmer and cattle herd share water points } \\
\text { on the trek with other herds }\end{array}$ & 3.1012 & 1.2700 & 22.22 & $1.84,267.83$ & 0.01 \\
\hline
\end{tabular}

*Model 2: Seven case herds with one seropositive animal and matched control herds are not included in the analysis

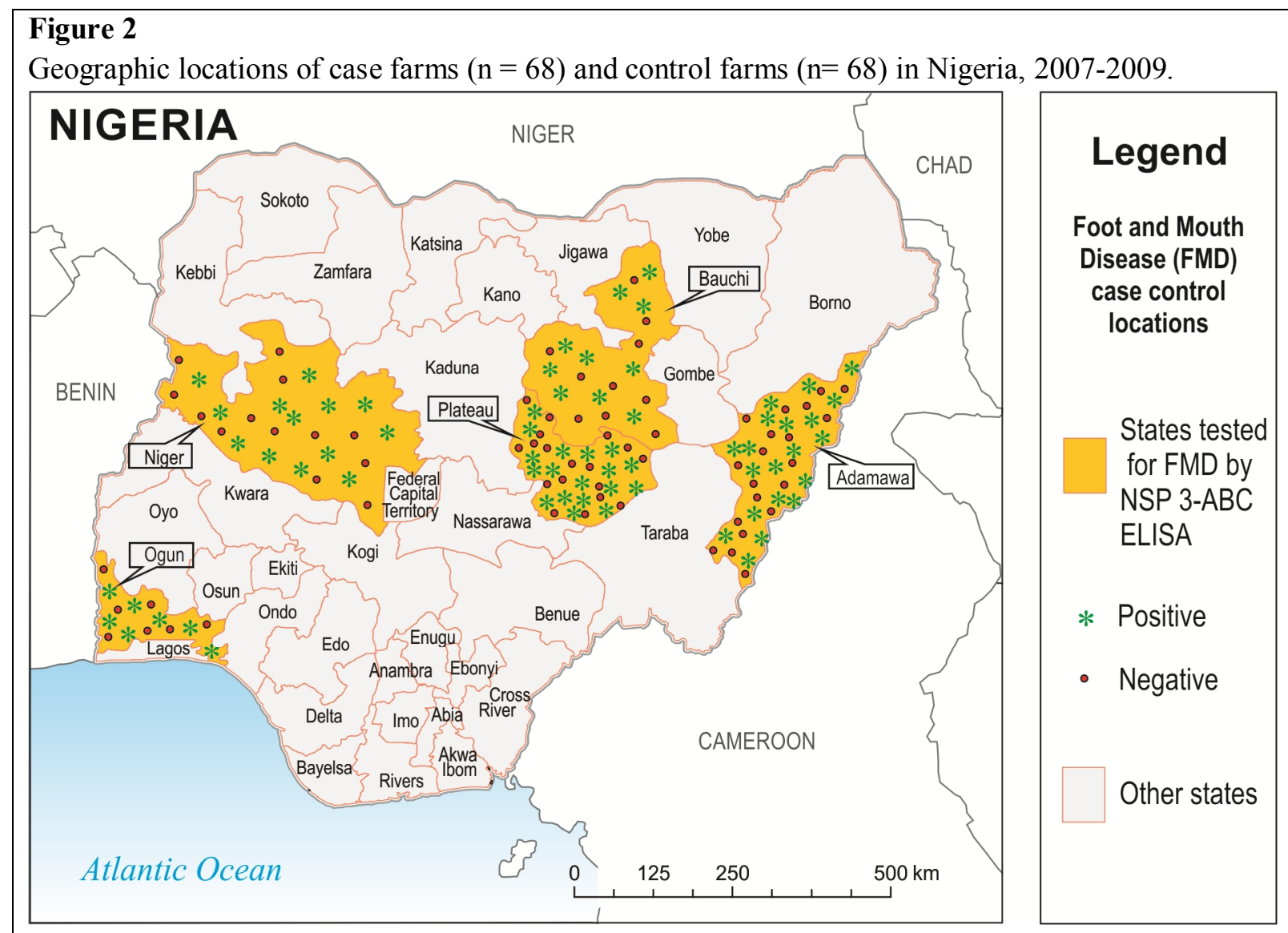




\section{Discussion}

\subsection{Identification of FMD virus strains}

This study provides evidence that FMDV serotypes O, A and SAT-2 were co-circulating in cattle herds in Nigeria during 2007-2009. Two serotype O isolates were recovered from one cattle herd in Bauchi state in 2007 and one cattle herd in Plateau state in 2009. The phylogenetic distance between these two isolates $=5.79 \%$, suggesting that the same virus has been in the region for 2 or more years and evolved from a common ancestor or that outbreaks in 2007 and 2009 were the result of separate FMDV introductions. In addition, the isolate from 2007 was considered the same strain as that from 3 isolates from Sudan in 2005 and 7 more in 2004. Furthermore, the isolate from 2009 was considered the same as that strain from 3 isolates from Sudan in 2005 (i.e., phylogenetic distance $<5 \%$ ). The spatial relationship between the two isolates from the states of Bauchi and Plateau can be explained by the migration of pastoralists and their cattle from Bauchi to Plateau during the dry season for pasture. During migration, cattle herds share water points on trek routes allowing for direct and indirect contact and for FMDV transmission to occur between cattle herds. The relationship between the two isolates from Nigeria in 2007 and 2009 and those from Sudan in 2004 and 2005 is difficult to explain because there were no closely related isolates from Central African Republic and Cameroon during 2007-2009. However, it is known that cattle are traded from Sudan across to Cameroon (through the Ngoui market on the border with the Central African Republic) near the border region with Nigeria (Bronsvoort et al., 2004).

Four serotype A (AFRICA, G-IV) isolates were recovered from one cattle herd in Plateau state (one isolate) and from one cattle herd in Adamawa state (three isolates) in 2009. The phylogenetic distance between two and one isolates from Adamawa $=0.16 \%$, and the distance 
between the isolates from Adamawa and Plateau $=11.38 \%$, suggesting that the origin of FMD outbreaks in these two states in 2009 was not the same. The phylogenetic distance between the four isolates from Nigeria and other isolates from Cameroon (2000), Mali (2004/2006) and Eritrea (1997) ranged from 6.26 to $11.53 \%$. Historically, pastoralists have moved southwards with their herds into Nigeria and Cameroon during the dry season and returned north again in the rainy season to avoid the tsetse fly. This serotype A (AFRICA, G-IV) virus has been endemic in Cameroon for many decades causing multiple outbreaks in cattle in the region (Bronsvoort et al., 2004). The relationships between the isolates from Nigeria and those from Mali and Eritrea are less clear, except for the well-known trade of cattle originating from Eritrea's neighboring country (Sudan) across to Cameroon (Bronsvoort et al., 2004), and subsequent exposure or potential exposure of susceptible cattle in Nigeria.

Nine serotype SAT-2 isolates were recovered from 1 cattle herd in Bauchi state in 2007, from 1 cattle herd in Niger state in 2008, and from 3 cattle herds in Plateau state in 2008. The phylogenetic distance between the nine isolates ranged from 0.31 to $1.39 \%$, suggesting that the same SAT-2 strain was circulating in these three states. Five of 9 isolates were from one sedentary (semi-intensive) herd in Niger state and 4 isolates were from one pastoralist herd in Bauchi state and from 3 pastoralist herds in Plateau state. In 2008, according to several reports from resident farmers and government documents, nomadic pastoralists trespassed other farm holdings (crop and livestock) in the course of their movements, causing conflicts in the north central Nigeria. Unrestricted movement of cattle herds and direct and indirect contact between infected and susceptible herds can explain this finding of FMDV infection with the same strain in both sedentary and pastoralist herds in Nigeria. 
The distance between the nine SAT-2 isolates from Nigeria and one isolate from Sudan (2007) ranged from 4.78 to $5.25 \%$. Similar to the relationship described above between serotype O isolates, the relationship between SAT-2 serotypes in Nigeria and Sudan can be explained by trade of cattle from Sudan across to Cameroon (through the Ngoui market on the border with the Central African Republic) near the border region with Nigeria (Bronsvoort et al., 2004). In addition, a previous investigation by a team of an epidemiologist and investigation officers from the NVRI at the Nigerian Gashaka-Gumti National Park (a national park that shared a lengthy boundary with Cameroon) in 2005 revealed that cattle enclaves within the Park were infected with FMD following conflicts between crop farmers and transhumance herdsmen. This situation forced cattle farmers to move with their cattle into the Cameroonian borders and back into Nigeria at the expiration of these conflicts. Finally, the phylogenetic distances between the nine isolates of SAT-2 from Nigeria and one isolate from the Niger Republic (2005) were from 7.10 to $7.25 \%$. Overall, these findings indicate that the same or similar SAT-2 strains have caused multiple outbreaks of FMD in Nigeria, Sudan, Niger Republic and, possibly, Cameroon for the last 10 years.

\subsection{Case-control study}

This study produced epidemiologic evidence that both direct and indirect transmission of FMD occurred between cattle herds caused by a neighborhood effect and by cattle herds sharing water points. Cattle herds in a neighborhood affected with FMD had higher odds of being classified as seropositive to FMD, compared to herds that were in a neighborhood not affected with FMD (adjusted $\mathrm{OR}=16.27 ; 95 \% \mathrm{CI}=3.61,18.74 ; P<0.01$ ). Neighborhoods in rural Nigeria allow

for direct and indirect contact between animals. Cattle herds are not confined in fenced premises. 
Usually, cattle (particularly calves) are not penned/tied down at night, and this practice can be a source of direct and indirect contact between cattle. A neighborhood effect for FMDV transmission between herds has been identified in other countries (Ellis-Iversen et al., 2011). Airborne spread of FMD from swine to nearby cattle and sheep, and an increase in the movements of vehicles and personnel engaged in disease control efforts perhaps facilitated local spread of FMD during the epidemic in the UK in 2001 (Mansley et al., 2011). During the outbreak in the UK in 2007, FMDV was accidently released from a joint vaccine production and diagnostic laboratory site in Pirbright, UK, most likely leaked through poorly maintained effluent pipes and transported off-site to two cattle farms nearby via mud or soil on vehicle wheels (EllisIversen et al., 2011). In that outbreak, a higher proportion of young stock was observed in case farms compared to other farms, suggesting an association between age and FMD status. In addition, inadequate biosecurity was identified as a risk factor for FMD transmission between cattle premises during the outbreak in 2007 (Mansley et al., 2011).

In this study, cattle herds that share water points along the trek routes with other cattle herds had higher odds of being classified as seropositive to FMD (adjusted OR $=4.15 ; 95 \% \mathrm{CI}=0.92$, 18.74; $\mathrm{P}<0.06)$. In Nigeria, there are established old grazing reserves and watering points along the trek routes, and animals originating from different locations share these reserves and watering points. In addition, rivers crossing the routes of these animals are shared by both FMDinfected and susceptible cattle herds which congregate together. A similar type of exposure and disease transmission between FMD-infected and susceptible animals has been documented in South Africa. At the Kruger National Park, between May and November, there is scarcity of water in the Park, and buffalo potentially infected with FMDV congregate around available 
water points providing an opportunity for direct and indirect contact with susceptible domestic livestock (Jori et al., 2009).

This study had several limitations. First, FMDV isolates were recovered from 15 of 50 epithelial/vesicular fluid samples submitted from cattle located in North Central and North East regions of Nigeria. No FMDV isolates were recovered from cattle in the South West region. It is possible that improper sample collection and processing (or packing) combined with a long distance and time required for samples to reach the NVRI in Vom could have affected the quality (freshness) of the sample to recover FMDV. Second, 7 of 68 case herds ( 3 from the state of Plateau, 3 from Bauchi, and 1 from Adamawa) had only one seropositive animal, and these herds were not confirmed as infected by virus isolation or rt-PCR. Because the 3-ABC ELISA test used in this study is not perfect (Brocchi et al., 2006; Engel et al., 2008), it is possible that one or more case herds were misclassified. Another limitation was observation (exposure) bias. For example, the accuracy of a producer to classify his/her cattle herd as vaccinated was not assessed in this study. In Nigeria and other countries in sub-Saharan Africa, the mobility and dispersion of nomadic pastoralists present significant financial and logistic constrains to veterinary services for vaccination of livestock.

Overall, the study results revealed that FMDV serotypes O, A and SAT-2 were co-circulating in cattle herds in Nigeria during 2007-2009. Based on results from the phylogenetic analysis, it is possible that the same SAT-2 strain has caused multiple outbreaks of FMD in cattle in Nigeria, Sudan, Niger Republic and, possibly, Cameroon for the last 10 years. Finally, combined results from the phylogenetic analysis and the case-control study suggest that FMD seropositivity in 
cattle herds was associated with exposure to neighborhoods with FMD activity and by cattle herds sharing water points. Results from this study can be used by veterinary services in Nigeria and neighboring countries to evaluate current or future FMD control and eradication programs.

\section{Acknowledgements}

The authors would like to appreciate David Paton, Jeff Hammond, Nick Knowles and their team at the IAH, World Reference Laboratory for Foot and Mouth Disease, Pirbright Laboratory, UK for their robust efforts in confirming the diagnosis and molecular studies and Mr. D. C. Nyam of the Viral Research Division for assistance during sampling. The National Animal Disease Information System (NADIS) teams are also thanked for prompt reporting of outbreaks and sample collection and the Management of the National Veterinary Research Institute, Vom for providing the environment for this study.

\section{References}

Brocchi, E., Bergmann, I., Dekker, A., Paton, D.J., Sammin, D.J., Greiner, M., Grazioli, S., De Simone, F., Yadin, H., Haas, B., Bulut, N., Malirat, V., Neitzert, E., Goris, N., Parida, S., Sorensen, K., De Clercq, K., 2006. Comparative evaluation of six ELISAs for the detection of antibodies to the non-structural proteins of foot-and-mouth disease virus. Vaccine 24, 6966-6979.

Bronsvoort, B.M. de C., Radford, A.D., Tanya, V.N., Nfon, C., Kitching, R.P., Morgan, K.L., 2004. Molecular epidemiology of foot and mouth disease viruses in the Adamawa Province of Cameroon. Journal of Clinical Microbiology 42 (5), 2186-2196.

Cytel Software Corporation, 2000. EGRET for Windows, 2000. Cytel Software Corp, Cambridge, MA, USA.

Durojaiye, A., 1981. Incidence of FMD in Oyo State of Nigeria, 1961-1981. Nig. Vet. J. 10, 713. 
Ellis-Iversen, J., Smith, R.P., Gibbens, J.C., Sharpe, C.E., Dominguez, M., Cook, A.J.C., 2011. Risk factors for transmission of foot and mouth disease during an outbreak in Southern England in 2007. Vet Rec 168:5 128: doi:10.1136/vr.c6364.

Engel, B., Buist, W., Orsel, K., Dekker, A., de Clercq, K., Grazioli, S., van Roermund, H., 2008. A Bayesian evaluation of six disgnostic tests for foot-and-mouth disease for vaccinated and nonvaccinated cattle. Prev. Vet. Med. 86, 124-138.

Fadiga, M., Jost, C., Ihedioha, J., 2011. Financial costs of disease burden, morbidity and mortality from priority livestock diseases in Nigeria: Disease burden and cost-benefit analysis of targeted intervention, Available at: http://www.ilri.org/content/financialcosts-disease-burden-morbidity-and-mortality-priority-livestock-diseases-nigeria. (accessed on 5 March, 2012).

Food and Agriculture Organization of the United Nations Statistics Division (FAOSTAT)., 2012. Stock (Head/Year): Nigeria, Available at: http://faostat.fao.org/site/573/DesktopDefault.aspx?PageID=573\#ancor. (accessed on $10^{\text {th }}$ April, 2012).

Food and Agriculture Organization of the United Nations (FAO) -WRLFMD Report on the Diagnosis of FMD, Nigeria, Available at: www.wrlfmd.org/fmd_genotyping/africa/nig.htm. (accessed on 23 March, 2012).

Hosmer, D.W., Lemeshow, S., 2000. Logistic regression for matched case-control studies. In: Hosmer, D.W., Lemeshow, S. (Eds.) Applied Logistic Regression. Wiley, New York, pp 223-259.

Jori, F., Vosloo, W., Du Plessis, B., Bengis, R., Brahmbhatt, D., Gummow, B., Thomson, G.R., 2009. A qualitative risk assessment of factors contributing to foot and mouth disease outbreaks in cattle along the western boundary of the Kruger National Park. Rev Sci Tech Int Epiz, 28 (3), 917-931.

Kitching, R.P. Donaldson, A.I., 1987. Collection and transportation of specimens for vesicular virus investigation. Rev. Sci. Tech. Off. Int. Epiz. 6, 263-272.

Knowles, N.J., Samuel, A.R., 2003. Molecular epidemiology of foot and mouth disease virus. Virus Research, 91, 65-80.

Libeau, J., 1960. Foot-and-mouth disease in Africa, South of the Sahara-The present situation. Bull. Epizoot. Dis. Afr. 8, 152-158.

Ma, L., Zhang, J., Chen, H., Zhou, J., Ding, Y., Liu, Y., 2011. An overview on ELISA techniques for FMD. Virology J. 208, 419.

Mansley, L.M., Donaldson, A.I., Thrushfield, M.V., Honhold, N., 2011. Destructive tension: Mathematics versus experience-the progress and control of the 2001 foot and mouth disease epidemic in Great Britain. Rev Sci Tech Int Epiz, 30(2), 483-498. 
Mason, P.W., Grubman, M.J., Baxt, B., 2003. Molecular basis of pathogenesis FMDV. Virus Res. 91, 9-32.

Nawathe, D.R., Goni, M., 1976. Foot-and-mouth disease in Nigeria. Bull. Anim. Health Prod. Afr. 24, 1-4.

OIE (World Organisation for Animal Health), 2008. Collection and shipment of diagnostic specimens, Chapter 1. 1. 1, Manual of Diagnostic Tests and Vaccines for Terrestrial Animals, Web version, 2008, Available at http://www.oie.int/eng/normes/mmanual/2008/pdf/1.1.01 COLLECTION.pdf. (accessed on $13^{\text {th }}$ September, 2008).

Orsel, K., Bouma, A., Dekker, A., Stegeman, J.A., de Jong, M.C.M., 2009. Foot and mouth disease virus transmission during the incubation period of the disease in piglets, lambs, calves and dairy cows. Preventive Veterinary Medicine 88, 158-163.

Owolodun, B.Y., 1971. Foot and mouth disease virus type distribution in Nigeria. Bulletin of Epizootic Diseases of Africa 8, 152-158.

Rweyemamu, M., Roeder, P., Mackay, D., Sumption, K., Brownlie, J., Leforban, Y., Valarcher, J.F., Knowles, N.J., Saraiva, V., 2008. Epidemiological patterns of foot-and-mouth disease worldwide. Transbound Emerg Dis. 55(1), 57-72.

Sahle, M., Venter, E.H., Dwarka, R.M., Vosloo, W., 2004. Molecular epidemiology of serotype $\mathrm{O}$ foot and mouth disease virus isolated from cattle in Ethiopia between: 1979-2001. Onderstepoort J Vet. 71, 129-38.

Sangare, O., Bastos, A.D., Venter, E.H., Vosloo, W., 2004. A first molecular epidemiological study of SAT-2 type foot-and-mouth disease viruses in West Africa. Epidemiol.Infect. 132(3), 525-532.

Sorensen, K.J., Madsen, K.G., Madsen, E.S., Salt, J.S., Nqindi, J., Mackay, D.K.J., 1998. Differentiation of infection from vaccination in foot-and-mouth disease by the detection of antibodies to the non-structural proteins 3D, 3AB and 3ABC in ELISA using antigens expressed in baculovirus. Arch Virol. 143, 1461-1476

Sumption, K., Pinto, J., Lubroth, J., Morzaria, S., Murray, T., De La Rocque, S., Njeumi, F., 2007. Foot-and-Mouth disease: Situation worldwide and major epidemiological events in 2005-2006. Emergency Prevention System (EMPRES) 2007, No. 1, Available at: http://www.fao.org/docs/eims/upload/225050/Focus_ON_1_07_en.pdf. (accessed on 9th April, 2012).

Vosloo, W., Dwarka, R.M., Bastos, A.D.S., Esterhuysen, J.J., Sahle, M., Sangare, O., 2004. Molecular epidemiological studies of Foot-and-Mouth disease virus in sub-Saharan Africa indicate the presence of large numbers of topotypes: implications for local and international control. Report of the Session of the Research Group of the Standing 
Technical Committee of the European Commission for the Control of Foot-and-Mouth Disease (EUFMD). Crete, Greece 2004, Available at:

http://www.fao.org/Ag/AGAInfo/commissions/docs/greece04/App22.pdf. (accessed on 9th April, 2012). 


\section{Appendix Table 1}

Serotype O isolates from Nigeria in 2007-2009 and most closely related viruses in Africa

\begin{tabular}{|c|c|c|c|c|}
\hline $\begin{array}{l}\text { Nigeria } \\
\text { Virus name }\end{array}$ & Topotype & $\begin{array}{l}\text { State in } \\
\text { Nigeria }\end{array}$ & $\begin{array}{c}\text { Most closely related viruses in Africa } \\
\text { Virus name }\end{array}$ & $\%$ identity $^{\mathrm{a}}$ \\
\hline $\mathrm{O} / \mathrm{NIG} / 1 / 2007$ & EA-3 & Bauchi & $\begin{array}{c}\mathrm{O} / \mathrm{SUD} / 3 / 2005 \\
\mathrm{O} / \mathrm{SUD} / 1 / 2005 \\
\mathrm{O} / \mathrm{SUD} / 2 / 2005 \\
\mathrm{O} / \mathrm{SUD} / 14 / 2004 \\
\mathrm{O} / \mathrm{SUD} / 15 / 2004 \\
\mathrm{O} / \mathrm{SUD} / 4 / 2004 \\
\mathrm{O} / \mathrm{SUD} / 1 / 2004 \\
\mathrm{O} / \mathrm{SUD} / 16 / 2004 \\
\mathrm{O} / \mathrm{SUD} / 25 / 2004 \\
\mathrm{O} / \mathrm{SUD} / 26 / 2004\end{array}$ & $\begin{array}{l}97.18 \\
97.03 \\
97.03 \\
96.24 \\
96.24 \\
96.24 \\
96.09 \\
96.09 \\
96.09 \\
96.09\end{array}$ \\
\hline $\mathrm{O} / \mathrm{NIG} / 15 / 2009$ & EA-3 & Plateau & $\begin{array}{c}\mathrm{O} / \mathrm{SUD} / 3 / 2005 \\
\mathrm{O} / \mathrm{SUD} / 1 / 2005 \\
\mathrm{O} / \mathrm{SUD} / 2 / 2005 \\
\mathrm{O} / \mathrm{NIG} / 1 / 2007 \\
\mathrm{O} / \mathrm{SUD} / 3 / 2004 \\
\mathrm{O} / \mathrm{SUD} / 14 / 2004 \\
\mathrm{O} / \mathrm{SUD} / 15 / 2004 \\
\mathrm{O} / \mathrm{SUD} / 4 / 2004 \\
\mathrm{O} / \mathrm{SUD} / 1 / 2004 \\
\mathrm{O} / \mathrm{SUD} / 16 / 2004\end{array}$ & $\begin{array}{l}95.45 \\
95.31 \\
95.31 \\
94.21 \\
94.05 \\
93.90 \\
93.90 \\
93.90 \\
93.74 \\
93.74\end{array}$ \\
\hline
\end{tabular}

${ }^{a}$ Source: FAO World Reference Laboratory for Foot-and-Mouth Disease. Genotyping Report. 


\section{Appendix Table 2}

Serotype A isolates from Nigeria in 2009 and most closely related viruses in Africa

\begin{tabular}{|c|c|c|c|c|}
\hline $\begin{array}{c}\text { Nigeria } \\
\text { Virus name }\end{array}$ & Topotype & $\begin{array}{l}\text { State in } \\
\text { Nigeria }\end{array}$ & $\begin{array}{c}\text { Most closely related viruses in Africa } \\
\text { Virus name }\end{array}$ & $\%$ identity $^{\mathrm{a}}$ \\
\hline $\mathrm{A} / \mathrm{NIG} / 3 / 2009$ & $\begin{array}{c}\text { AFRICA, } \\
\text { G-IV }\end{array}$ & Plateau & $\begin{array}{c}\mathrm{A} / \mathrm{CAR} / 12 / 2000 \\
\mathrm{~A} / \mathrm{CAR} / 13 / 2000 \\
\mathrm{~A} / \mathrm{CAR} / 14 / 2000 \\
\mathrm{~A} / \mathrm{CAR} / 15 / 2000 \\
\mathrm{~A} / \mathrm{CAR} / \mathrm{P} 19 / 2000 \\
\mathrm{~A} / \mathrm{NIG} / 36 / 2009 \\
\mathrm{~A} / \mathrm{NIG} / 39 / 2009 \\
\mathrm{~A} / \mathrm{MAI} / 12 / 2004 \\
\mathrm{~A} / \mathrm{MAI} / 4 / 2006 \\
\mathrm{~A} / \mathrm{NIG} / 38 / 2009\end{array}$ & $\begin{array}{l}90.88 \\
90.88 \\
90.88 \\
90.88 \\
90.57 \\
89.62 \\
89.62 \\
89.47 \\
89.47 \\
89.47\end{array}$ \\
\hline $\begin{array}{l}\mathrm{A} / \mathrm{NIG} / 36 / 2009^{\mathrm{b}} \\
\mathrm{A} / \mathrm{NIG} / 39 / 2009^{c}\end{array}$ & $\begin{array}{c}\text { AFRICA, } \\
\text { G-IV }\end{array}$ & Adamawa & $\begin{array}{c}\mathrm{A} / \mathrm{NIG} / 38 / 2009 \\
\mathrm{~A} / \mathrm{CAR} / 12 / 2000 \\
\mathrm{~A} / \mathrm{CAR} / 13 / 2000 \\
\mathrm{~A} / \mathrm{CAR} / 14 / 2000 \\
\mathrm{~A} / \mathrm{CAR} / 15 / 2000 \\
\mathrm{~A} / \mathrm{CAR} / \mathrm{P} 19 / 2000 \\
\mathrm{~A} / \mathrm{MAI} / 4 / 2004 \\
\mathrm{~A} / \mathrm{MAI} / 12 / 2006 \\
\mathrm{~A} / \mathrm{CAR} / \mathrm{P} 22 / 2000\end{array}$ & $\begin{array}{l}99.84 \\
93.74 \\
93.74 \\
93.74 \\
93.74 \\
93.43 \\
91.08 \\
90.77 \\
90.61\end{array}$ \\
\hline $\mathrm{A} / \mathrm{NIG} / 38 / 2009^{\mathrm{d}}$ & $\begin{array}{c}\text { AFRICA, } \\
\text { G-IV }\end{array}$ & Adamawa & $\begin{array}{c}\mathrm{A} / \mathrm{NIG} / 36 / 2009 \\
\mathrm{~A} / \mathrm{NIG} / 39 / 2009 \\
\mathrm{~A} / \mathrm{CAR} / 12 / 2000 \\
\mathrm{~A} / \mathrm{CAR} / 13 / 2000 \\
\mathrm{~A} / \mathrm{CAR} / 14 / 2000 \\
\mathrm{~A} / \mathrm{CAR} / 15 / 2000 \\
\mathrm{~A} / \mathrm{CAR} / \mathrm{P} 19 / 2000 \\
\mathrm{~A} / \mathrm{MAI} / 4 / 2004 \\
\mathrm{~A} / \mathrm{ERI} / 3 / 1997 \\
\mathrm{~A} / \mathrm{MAI} / 12 / 2006\end{array}$ & $\begin{array}{l}99.84 \\
99.84 \\
93.58 \\
93.58 \\
93.58 \\
93.58 \\
93.27 \\
90.92 \\
90.61 \\
90.61\end{array}$ \\
\hline
\end{tabular}

${ }^{a}$ Source: FAO World Reference Laboratory for Foot-and-Mouth Disease. Genotyping Report.

${ }^{\text {bcd }}$ These three isolates are from three different herds in the same neighborhood in the state of Adamawa 
Appendix Table 3 Serotype SAT-2 isolates from Nigeria in 2009 and most closely related viruses in Africa

\begin{tabular}{|c|c|c|c|c|}
\hline $\begin{array}{c}\text { Nigeria } \\
\text { Virus name } \\
\end{array}$ & Topotype & $\begin{array}{l}\text { State in } \\
\text { Nigeria }\end{array}$ & $\begin{array}{c}\text { Most closely related viruses in Africa } \\
\text { Virus name }\end{array}$ & $\%$ identity $^{\mathrm{a}}$ \\
\hline $\begin{array}{l}\mathrm{SAT}-2 / \mathrm{NIG} / 2 / 2007 \\
\mathrm{SAT}-2 / \mathrm{NIG} / 5 / 2008^{\mathrm{b}}\end{array}$ & VII & $\begin{array}{l}\text { Bauchi } \\
\text { Plateau }\end{array}$ & $\begin{array}{c}\text { SAT-2/NIG/6/2008 } \\
\text { SAT-2/NIG/7/2008 } \\
\text { SAT-2/NIG/1/2008 } \\
\text { SAT-2/NIG/2/2008 } \\
\text { SAT-2/NIG/3/2008 } \\
\text { SAT-2/NIG/4/2008 } \\
\text { SAT-2/NIG/8/2008 } \\
\text { SAT-2/SUD/1/2007 } \\
\text { SAT-2/NGR/15/2005 }\end{array}$ & $\begin{array}{l}99.69 \\
99.69 \\
98.92 \\
98.92 \\
98.92 \\
98.92 \\
98.92 \\
95.06 \\
92.75\end{array}$ \\
\hline $\begin{array}{l}\mathrm{SAT}-2 / \mathrm{NIG} / 1 / 2008^{\mathrm{e}} \\
\mathrm{SAT}-2 / \mathrm{NIG} / 2 / 2008^{\mathrm{e}} \\
\mathrm{SAT}-2 / \mathrm{NIG} / 3 / 2008^{\mathrm{e}} \\
\mathrm{SAT}-2 / \mathrm{NIG} / 8 / 2008^{\mathrm{e}}\end{array}$ & VII & $\begin{array}{l}\text { Niger } \\
\text { Niger } \\
\text { Niger } \\
\text { Niger }\end{array}$ & $\begin{array}{c}\mathrm{SAT}-2 / \mathrm{NIG} / 4 / 2008 \\
\mathrm{SAT}-2 / \mathrm{NIG} / 2 / 2007 \\
\mathrm{SAT}-2 / \mathrm{NIG} / 5 / 2008 \\
\mathrm{SAT}-2 / \mathrm{NIG} / 6 / 2008 \\
\mathrm{SAT}-2 / \mathrm{NIG} / 7 / 2008 \\
\mathrm{SAT}-2 / \mathrm{SUD} / 1 / 2007 \\
\mathrm{SAT}-2 / \mathrm{NGR} / 15 / 2005\end{array}$ & $\begin{array}{l}99.69 \\
98.92 \\
98.92 \\
98.61 \\
98.61 \\
95.22 \\
92.90\end{array}$ \\
\hline SAT-2/NIG/4/2008 & VII & Niger & $\begin{array}{c}\mathrm{SAT}-2 / \mathrm{NIG} / 1 / 2008 \\
\mathrm{SAT}-2 / \mathrm{NIG} / 2 / 2008 \\
\mathrm{SAT}-2 / \mathrm{NIG} / 3 / 2008 \\
\mathrm{SAT}-2 / \mathrm{NIG} / 8 / 2008 \\
\mathrm{SAT}-2 / \mathrm{NIG} / 2 / 2007 \\
\mathrm{SAT}-2 / \mathrm{NIG} / 5 / 2008 \\
\mathrm{SAT}-2 / \mathrm{NIG} / 6 / 2008 \\
\mathrm{SAT}-2 / \mathrm{NIG} / 7 / 2008 \\
\mathrm{SAT}-2 / \mathrm{SUD} / 1 / 2007 \\
\mathrm{SAT}-2 / \mathrm{NGR} / 15 / 2005\end{array}$ & $\begin{array}{l}99.69 \\
99.69 \\
99.69 \\
99.69 \\
98.92 \\
98.92 \\
98.61 \\
98.61 \\
95.22 \\
92.90\end{array}$ \\
\hline $\begin{array}{l}\mathrm{SAT}-2 / \mathrm{NIG} / 6 / 2008^{\mathrm{c}} \\
\mathrm{SAT}-2 / \mathrm{NIG} / 7 / 2008^{\mathrm{d}}\end{array}$ & VII & $\begin{array}{l}\text { Plateau } \\
\text { Plateau }\end{array}$ & $\begin{array}{c}\text { SAT-2/NIG/2/2007 } \\
\text { SAT-2/NIG/5/2008 } \\
\text { SAT-2/NIG/1/2008 } \\
\mathrm{SAT}-2 / N I G / 2 / 2008 \\
\mathrm{SAT}-2 / \mathrm{NIG} / 3 / 2008 \\
\mathrm{SAT}-2 / \mathrm{NIG} / 4 / 2008 \\
\mathrm{SAT}-2 / \mathrm{NIG} / 8 / 2008 \\
\mathrm{SAT}-2 / \mathrm{SUD} / 1 / 2007 \\
\mathrm{SAT}-2 / \mathrm{NGR} / 15 / 2005\end{array}$ & $\begin{array}{l}99.69 \\
99.69 \\
98.61 \\
98.61 \\
98.61 \\
98.61 \\
98.61 \\
94.75 \\
92.75\end{array}$ \\
\hline
\end{tabular}

${ }^{\mathrm{a}}$ Source: FAO World Reference Laboratory for Foot-and-Mouth Disease. Genotyping Report.

bcd These three isolates are from three different herds in the same neighborhood in the state of Plateau ${ }^{\mathrm{e}}$ These five isolates are from one cattle herd in the state of Niger. 